$$
\text { ilmiyat }
$$

Tokat IImiyat Dergisi | Tokat Journal of IImiyat

9/1 (Haziran | June 2021)

ISSN 2717-6134 | e-ISSN 2717-610X

\title{
Bir Osmanlı Entelektiielinin Bakışıyla İstanbul Şehir Hayatı (20. yüzyıl)
}

Istanbul City Life from the Perspective of an Ottoman Intellectual (20th century)

\section{Tuğba AYDENiz}

Dr. Öğr. Üyesi, Karabük Üniversitesi Asst. Prof., Karabük University Illahiyat Fakültesi Faculty of Theology

İslam Tarihi ve Sanatları Ana Bilim Dalı Department of İslamic History and Arts Karabük|Türkiye Karabük|Turkey tubayaln@gmail.com orcid.org/0000-0002-3170-9675

\section{Makale Bilgisi | Article Information}

Makale Türü | Araştırma Makalesi Article Types | Research Article Gelis Tarihi | 18 Mart 2021 Received | 18 March 2021 Kabul Tarihi | 14 Haziran 2021 Accepted | 14 June 2021

Yayın Tarihi | 30 Haziran 2021 Published | 30 June 2021

\section{Atıf | Cite as:}

Aydeniz, Tuğba. "Bir Osmanlı Entelektüelinin Bakışıyla İstanbul Şehir Hayatı (20. yüzyıl) [Istanbul City Life from the Perspective of an Ottoman Intellectual (20th century)]". Tokat IImiyat Dergisi | Tokat Journal of Ilmiyat 9/1 (Haziran | June 2021), 347-373. https://doi.org/10.51450/ilmiyat.896733

\section{Intihal | Plagiarism:}

Bu makale, iTenticate aracılığıyla taranmış ve intihal içermediği teyit edilmiştir. I This article, has been scanned by iThenticate and no plagiarism has been detected.

\section{Copyright $\odot$}

Published by Tokat Gaziosmanpaşa University Faculty of Islamic Sciences. Tokat | Turkey. https://dergipark.org.tr/ilmiyat 


\section{Istanbul City Life from the Perspective of an Ottoman Intellectual}

(20th century)

Abstract: Ahmed Șāfî Bey (1851-1926) is an intellectual who has been witnessed the last period of the Ottoman Empire and the first three years of the founding process of the Republic. The most striking one among the works he wrote is his work named "Safina al-Säfi". The work consists of 18 volumes. Although it does not comply with the definitions of encyclopedia in today's conditions, it can be considered as an encyclopedia because it deals with different subjects such as theology, history, history of Istanbul, Islamic history, literature, sufi tradition, cuisine culture, astrology, Persian and Arabic poems. However, all these subjects and issues are not classified in his work. The 16th and 18th volumes of Safina provide extensive information on the history of Istanbul. In this article, the writings on Istanbul in the 16th and 18th volumes of Safina were examined. In this study, the content of both volumes has been classified under several main titles according to their subjects in terms of Istanbul history. These titles are; Istanbul and Natural Disasters, Transportation in Istanbul, Ancient Historical Treasures of Istanbul, Game Animals of the City, Istanbul and Tulips. Titles have been formed under these themes. Ahmed Șāfĩ used and benefited from some sources in his writings on Istanbul. These sources are books and newspaper copies as written sources. In addition, his personal observations, experiences and what he heard from his environment are the sources of his writing. He focuses in his writings all the periods and many aspects of City Life. In particular, he does not approve of the changes that the city has experienced in recent times. One of these changes is in the architectural field that emerged with the effect of Westernization. The tulip era is at the beginning of the periods that he criticized the most. After that respectively, the periods in which the criticism was directed the most were the period of Abdulmecid, Abdulaziz and Abdulhamid's reign. The main emphasis of these criticisms is the deterioration of the state, weakening of the administration, unawareness and insensitivity of the rulers to the needs of the people, the change of architectural structure of Istanbul, and the financial mismanagement and waste in the expenditures of the palace. Ahmed Șâfi Bey did not suggest, mention or write any solution for these problems he criticizes in the book but the back longing for the past days of the Ottoman Empire. According to him, the beginning of corruption follows the reign of Suleiman the Magnificent. The followed period of Suleiman had been a period of Western imitation, and unqualified administrators came to power. According to him, improvement can only be possible by returning to the ancient times of the Ottoman Empire. Ahmed Sāfī, dissatisfied with the Ottoman administration but embraced Mustafa Kemal Atatürk, the founder of the Turkish Republic, as a savior. The main concepts and terms are seen in his writing are progress (taraqqī), ancient periods (āsār-1 kadīma), the absence of meritocratic bureaucracy (kahț-1 ricāl), advance and fall behind etc. The Safina provides the opportunity to observe the changes that Istanbul has gone through. The increasing studies on the Safina will contribute to the detailed knowledge of some subjects in terms of Istanbul history. Thus, it will help us to see what had happened during the transition from the Ottoman Empire to the Republic from an intellectual view living at that time.

Keywords: History, Ottoman, Istanbul, Ahmed Șāfī Bey, Safīna al-Ṣāfī. 


\section{Bir Osmanlı Entelektïelinin Bakışıyla İstanbul Şehir Hayatı}

(20. yüzyil)

Öz: Ahmed Sâfî Bey (1851-1926) Osmanlı'nın son dönemini ve Cumhuriyet'in ilanının ilk üç senesini görmüş bir entelektüeldir. Yazmış olduğu eserler içerisinde en dikkat çekeni "Sefînetü's-Sâfî" isimli eseridir. Eser 18 ciltten oluşmaktadır. Günümüz şartlarında ansiklopedi tanımlarına uymasa da kelâm, tarih, İstanbul tarihi, İslam tarihi, edebiyat, tasavvuf, mutfak kültürü, ilm-i nücum, Farsça ve Arapça şiirler gibi farklı konuları ele alması sebebiyle ansiklopedi olarak sayılabilir. Ancak bu konular eserinde tasnif edilmemiştir. Sefîne'nin 16 ve 18. ciltleri İstanbul tarihine dair geniş malumat verir. Bu makalede Sefîne'nin 16 ve 18.ciltlerinde İstanbul üzerine yazılan yazılar incelenmiştir. Eserin şehir tarihine/İstanbul tarihine kaynak olma özelliği ele alınmıştır. Her iki ciltte yer alan İstanbul ile ilgili yazılar konularına göre birkaç başlıkta tasniflenmiştir. Bu başlıklar; İstanbul ve Tabii Âfetler, İstanbul'da Ulaşım, İstanbul'un Kadim Tarihi Hazineleri, Şehrin Av Hayvanları, İstanbul ve Laledir. Bu temaların altında başlıklar teşkil edilmiştir. Ahmed Sâfî Bey'den bazı alıntılarla konu zengin bir şekilde işlenmiştir. Ahmed Sâfî Bey İstanbul üzerine yazdığı yazılarda bazı kaynaklardan yararlanmıştır. Bunlar, yazılı kaynaklar olarak kitaplar ve gazete nüshalarıdır. Bundan başka şahsî gözlemleri, tecrübeleri, çevresinden dinlemiş oldukları da onun kaynaklarını oluşturur. Ahmed Sâfî Bey'in İstanbul'a olan ilgisi bir bütündür. Şehrin geçirdiği tüm dönemleri benimser. Bilhassa son dönemlerde şehrin yaşamış olduğu değişimleri ise tasvip etmemektedir. Bu değişimin başında Batılılaşma tesiri ile ortaya çıan mimari değişiklikler gelmektedir. Lale devri en çok tenkit ettiği dönemlerin başındadır. Sultan Abdülmecid ve Sultan Abdülaziz dönemini, II. Abdülhamid'in saltanatını sert üslûbuyla eleştirir. Bu tenkitlerinin merkezinde devlette bozulma, idarenin zayıflaması, yöneticilerin halkın ihtiyaçlarından habersiz olması, İstanbul'un imarı, sarayın harcamalarındaki israf gibi konular gelmektedir ancak bu tenkitleri için bir çözüm yolu teklif etmez. Osmanlı'nın geçmiş günlerine dair bir yakınma ve hasret duyar. Ona göre bozulma aslında Kanuni Sultan Süleyman döneminden sonra ortaya çıkmıştır. Kanuni sonrası Batı taklidinin olduğu bir dönemdir ve Kanuni sonrasında basiretsiz idareciler iktidara gelmiştir. Dolayısıyla başarılı bir idareden söz edilemez. Ona göre düzelme ancak bu eskiye dönüşle mümkün olabilir. Osmanlı idaresinden memnun olmayan Ahmed Sâfî Bey, Türkiye Cumhuriyeti'nin kurucusu Mustafa Kemal'i bir kurtarıcı olarak benimsemiştir. Yazılarında terakki, âsâr-1 kadime, kaht-1 rical, ilerlemek-geri kalmak gibi kavramlar dikkati çekmektedir. Sefîne, İstanbul'un geçirdiği değişimleri izlemeye imkân sağlar. Rahat okunan ve anlaşılır bir dile sahiptir. Onu bir İstanbul tarihçisi olarak da görmek mümkündür. Ancak bazı yazılarında herhangi bir kaynak kullanmaması, iddia ettiği konuda şüpheye yol açabilir. Bu yüzden bazı yorumları aşırı veya sübjektif olabilir. Yazdıkları, farklı disiplinlerin çalışmalarına imkân vermektedir. Bunları özellikle kültür tarihi ve kültür sosyolojisi çerçevesinde değerlendirmek mümkündür. Sefîne üzerine yapılacak çalışmaların çoğalması İstanbul tarihi açısından bazı konuların detaylı bilinmesine katkı sağlayacaktır. Böylece Osmanlı'dan Cumhuriyet'e geçişte yaşananları o dönem yaşayan bir entelektüelden görmemize yardımcı olacaktır.

Anahtar Kelimeler: Tarih, Osmanlı, İstanbul, Ahmed Sâfî Bey, Sefînetü's-Sâfî. 


\section{Giriş}

Tatlıdilzâde Ahmed Sâfî Bey, kaleme aldı̆̆ı yazılarla kültür tarihimi-

1 ze önemli katkılar sağlamış bir isimdir. Hayatı hakkında, en meşhur eseri Sefinetü's-Sâfì de yazdıkları, bildiklerimizin bir kısmını oluşturmaktadır. Ancak hem şahsına hem de eserine dikkat çeken makale ve tez çalışmaları Sefinetü's-Sâfì ye artan bir ilginin olduğunu göstermektedir. ${ }^{1}$ Bu çalışmaların ilkini oluşturan "Kültür Tarihimize Işık Tutan Mühim Bir Kaynak: Sefînetü's-Sâfî” isimli makalede Ahmed Sâfî Bey'in kendi ağzından hayat hikayesine yer verildikten sonra 18 ciltlik eserinin muhtevası verilerek genel anlamda tanıtımı yapılmıştır. ${ }^{2}$ Diğer bildiri ve makalelerde ise Ahmed Sâfî Bey'in Sefinetü’s-Sâfîde yazdığı bazı konular müstakil incelenmiştir.

Bu makalede, Ahmed Sâfî Bey'in Sefinetü's-Sâfî isimli 18 ciltlik eserinin 16. ve 18. ciltlerinde İstanbul ile ilgili yazdıkları konular değerlendirilecektir. Bu iki cildin seçilme gerekçesi; müellifin İstanbul tarihi hakkında farklı ve dikkat çekici bilgiler sunmasından kaynaklanmaktadır. ${ }^{3}$ Ciltlerin tümüne bakıldığında 18. cildin İstanbul tarihine dair önemli malumata sahip olduğu görülmektedir. Ahmed Sâfî Bey'in Sefine'sinin birçok alanda yazılan farklı konuları içine aldığını göz önünde bulundurduğumuzda eserin tanıtımına katkı sağlamak da temel amaçlardan birisidir. Günümüz şartlarındaki ansiklopedi tanımları ve kabulleri çerçevesinde olmasa da Sefîne'nin farklı konuları bünyesinde barındıran bir ansiklopedi niteliği taşıdığı ve dönemi itibariyle özgün bir yere sahip olduğu söylenebilir.

\section{Hayatı}

Ahmed Sâfî Bey, Sefinetü's-Sâfîye göre 22 Rebîülâhir 1267/24 Şubat 1851 yılında İstanbul'un Bahçekapı semtinde doğmuştur. Aldı̆̆ı Arapça

1 Necdet Tosun, “Ahmed Sâfî Bey”, Türkiye Diyanet Vakfi İslâm Ansiklopedisi (İstanbul: TDV Yayınlar1, 2016) EK-1/50-51; Cemal Kurnaz-Mustafa Tatc1, "Ahmed Sâfî Bey’in Türk Dili ile İlgili Düşünceleri”, TDI 583 (2000), 25-27; Mustafa Tatç1, “Ahmet Sâfî Bey’in Çiçekleri”, Dergâh 187 (Eylül 2005), 19-21; Mustafa Tatçı-Yusuf T. Günaydın, "Ahmed Sâfî Bey’in Süleymaniye Camii Hakkındaki Düşünceleri”, Süleymaniye Ulusal Sempozyumu/Şehir ve Medeniyet, ed. Mustafa Hakk1 Ertan vd., (İstanbul: KOCAV, 2007), 114-121; Murat Ak, "Ahmed Sâfî Bey'in Kasîde-i Hamriyye Tercümesi”, Turkish Studies, 11/17 (2016), 131-150; Mehmet Tıraşc1-Mustafa Özfidan, "Ahmed Sâfî̀nin Sefînetü’s-Sâfî’sinde Mûsıkî Bölümleri ve Ud'la İlgili Kısmın İncelenmesi”, Cumhuriyet İlahiyat Dergisi 21/2 (2017), 1249-1266; Serap Aktaş, Ahmed Sâfi Bey'in Sefinetü's-Sâfi Adlı Eserinde Bektaşîlik (İstanbul: Marmara Üniversitesi, Sosyal Bilimler Enstitüsü, Yüksek Lisans Tezi, 1999); Mustafa Karataş, Ahmed Sâfî Bey'in Sefinetü's-Sâfî Adlı Eserinin VIII. Cildinin Neşri ve Ruh, Âlem-i Ervâh Açısından Değerlendirilmesi (İstanbul: Marmara Üniversitesi, Sosyal Bilimler Enstitüsü, Yüksek Lisans Tezi, 1999).

2 Necdet Tosun, "Kültür Tarihimize Işık Tutan Mühim Bir Kaynak: Sefînetü’s-Sâfî", ILAM Araștırma Dergisi 1/2 (Temmuz-Aralık 1996), 177-190.

3 Sefinetü's-Sâfi, Prof. Dr. Hür Mahmut Yücer'in koordinesinde bu makalenin yazarının da içinde bulunduğu bir grup akademisyen tarafından 2016 yılından itibaren yürütülen bir çalışma ile günümüz Türkçesine aktarılmıştır.

4 Aynı bilgiyi eserin son cildinde Ahmed Sâfî Bey’in oğlu da nakleder. Bk. Ahmed Sâfî Bey, 
ve Farsça eğitimlerle ${ }^{5}$ edebî bir derinliğe sahip olduğu, Sefinetü's-Sâfíde yazdıklarından anlaşılmaktadır. Devletin çeşitli kademelerinde çalışmıştır. 1913 tarihinde emekli olmuş, Sefine'yi yazmaya başlamış, 1924 yılında tamamlamıştır. Ölümünden bir yıl önce Özbekler Dergâhı'nda cuma akşamları Mesnevî okutmuştur. ${ }^{6}$ Oğlu İbrahim Bey'in verdiği bilgiye göre hiçbir hastalığı yokken 24 Mayıs 1926 Pazartesi günü vefat etmiş ve Anadolu Kavağı'ndaki Büyük Şehitliğe defnedilmiştir. ${ }^{7}$ Vefatından sonra bazı yazıları Şule ve Mecmuam isimli iki risale olarak yayımlanmıştır. Divan'ı ise basılmamıştır.

Fizikî olarak "orta boylu, beyaz ve kısa sakallı, gözlüklü, esmer, zayıf, halim, beşuş, mütedeyyin, daniş ehli" olarak nitelenen Ahmed Sâfî Bey'in ${ }^{9}$ bazı yazılarında ve şiirlerinde ismini kullanmadığı için şöhreti sevmediği söylenir. Nakşiyye-i Halidiyye'den İsmet Efendi'ye bağlanmıștır. ${ }^{10}$ Ahmed Sâfî Bey, "İbn Arabî”nin düşüncelerine bağlı, Hurûfiliğe ve simya ilmine meraklı melâmî meşrep"tir. ${ }^{11}$

Ahmed Sâfî Bey, İbnü'l-Emin, Hüseyin Vassâf, Mehmed Tahir gibi devrin önemli simaları ile teşrikimesaide bulunmuş bir zattır. Kendisinin hayatı hakkında bilinenlerin çoğu, kaleme aldığı mektuplardan veya dost meclisinde geçen sohbetlerden öğrenilmektedir. ilim meclislerinin aranılan yüzü olduğu Süheyl Ünver'in Arşivi'nde yer alan bazı kayıtlarda da dikkati çekmektedir. ${ }^{12}$ Ünver' in Seyit Nizam Camii ve Tekkesi'nin harap halinden etkilenerek, 1970 yılında tuttuğu bir notta yer alan, "Bundan 60 sene önce Nazmi Dede'nin Nâil Efendi ve Sefine-i Safi sahibi Ahmed Sâfî Efendi ile Şeyhi Şuca Efendi ile oturup sohbet edilen yerde yeller esiyor." cümlesi buna işaret etmektedir. ${ }^{13}$

Ahmed Sâfî Bey, Sefinetü's-Sâfînin satır aralarında, yazmakta olduğu ancak tamamlayıp tamamlamadığı belli olmayan bir "Evkâf-ı Ümem Tarihi"nden ${ }^{14}$ bahsetmiş ve kaleme aldığ 1 Gül Baba Risalesi'ne yer

Sefinetü's-Sâfî, (İstanbul: İstanbul Üniversitesi Tip Fakültesi Tıp Tarihi Müzesi, 746), 18. cildin son sayfasi numarasız.

5 İbnü'l-Emin Mahmud Kemal İnal, Son Astr Türk Şairleri, haz. İbrahim Baştuğ (Ankara: Atatürk Kültür Merkezi Başkanlığı Yayınları, 2002), 4/2035; Osmânzâde Hüseyin Vassâf, Sefine-i Evliyâ, haz. Mehmet Akkuş-Ali Yılmaz (İstanbul: Kitabevi, 2006), 4/216.

6 İnal, Son Astr Türk Şairleri, 4/2035.

7 Ahmed Sâfî Bey, Sefine, 18/numarasız.

İnal, Son Astr Türk şairleri, 4/2036.

İnal, Son Astr Türk Şairleri, 4/2036.

${ }^{10}$ Vassâf, Sefine-i Evliyâ, 4/217.

${ }^{11}$ Tosun, "Mühim Bir Kaynak", 178.

${ }^{12} \mathrm{Bu}$ arşivdeki belgelerden beni haberdar eden Yozgat Bozok Üniversitesi Sosyal Bilimler Meslek Yüksekokulu Öğretim Görevlisi Kâmil Büyüker'e teşekkür ederim.

${ }^{13}$ Süleymaniye Kütüphanesi(SK), Süheyl Ünver Dosyası, No. 304/7, 10.

${ }^{14}$ Ahmed Sâfî Bey, Sefinetü's-Sâfí, (İstanbul: İstanbul Üniversitesi Tip Fakültesi Tıp Tarihi Müzesi, 744), 16/2499. 
vermiştir. ${ }^{15}$ Bunlardan başka yazmaya niyet ettiği hatta yazmaya başladı̆̆1 ve Rehnümấ-yı Konstantiniyye ismini verdiği bir İstanbul gezi rehberinden söz etmektedir. Rehberi yazma gerekçesini, "İstanbul hakkında ecnebilerin ellerinde bulunan yalan yanlış yazılmış rehberlerden müstağni olmak ve vatanıma bir hizmet-i müftehirede bulunmak üzere bundan takriben kırk sene evvel (Rehnümâ-yı Konstantiniyye) nâmıyla yazmak arzusunda bulunmak" şeklinde açıklar. Büyük zahmetler harcayarak yazmaya çalıştığı rehberin muhtevası hakkında ise şu bilgileri verir:

"Bilir misin ne zahmetler çektim ne emekler sarf ettim. Ne kadar makberler taharri eyledim. Bu kitabın vücûda gelmesiçün otuz küsur Osmanlı altını haraç ettim. Hepsi hebâ oldu. Bu kitabın bir sahifesi Türkçe karşıki sahifesi Fransızca olup her bir mahallenin hudûduyla beraber o mahallede ne gibi şeyler bulunduğunu gerek Bizans meşâhirinden gerek e'âzim-i ümmetten kimler medfûn olduklarını elde edilebilen tercüme-i hâlleri yazılarak ve makberleri gösterilerek o mahallenin ufacık bir haritası oraya rabt olunacak ve o harita kitabın sonundaki İstanbul'un umûm haritasina konulacak idi. Avrupa'dan İstanbul'u ziyarete gelen her bir seyyah bu Rehnümâ kitabından bir kıtasını mubayaaya mecbur olurdu. Kitabı iki franga Avrupa şehirlerinde satar, bir hayli menâfi-i maddiye de elde eder idim; hayfa ki ikmâline muvaffak olamadım." ${ }^{16}$

Ahmed Sâfî Bey'in bu eseri tamamlamaya muvaffak olamamasının sebebi, II. Abdülhamid döneminde uygulanan sansüre takılacağını, hatırlı dostlarının kendisine ikazda bulunmalarıdır. Bu sebeple rehberin büyük kısmını teşkil eden yazıları gaz tenekeleri içinde yakar.

Esasında kitaplara uygulanan sansür, Sultan II. Abdülhamid döneminden önce de mevcuttur. Bu konuda ilk olarak 1857 yılında Matbaa Nizamnamesi çıkarılmıştır. Basılacak kitapların denetimi ve basımı için ruhsat verilmesi kararı Meclis-i Maarif'e bırakılmıştır. Abdülhamid döneminde ise 1888 ve 1894 tarihlerinde yeni nizamnameler çıkarılmasının dışında kitap basımının denetlenmesi için heyetler kurulmuştur. Zamanla artan iş yükü sebebiyle 1895 yılında dışarıdan gelen kitap ve risalelerin tetkiki için ayrı bir heyet oluşturulmuştur. Bu heyetin kitapların basılmasına müsaade etmeme gerekçelerinde dinî, ahlakî, siyasi açıdan uygun bulunmaması ön planda olduğu gibi herhangi bir açıklama olmadan da bazı kitapların basılmasına izin verilmeyebilmektedir. ${ }^{17}$ Isste, Ahmed Sâfî Bey’i

\footnotetext{
${ }^{15}$ Ahmed Sâfî Bey, Sefine, 16/2667.

${ }^{16}$ Ahmed Sâfî Bey, Sefine, 18/3128-3129.

${ }^{17}$ Fatmagül Demirel, II. Abdülhamid Döneminde Sansür (İstanbul: Bağlam Yayıncılık, 2007), 89-96. Abdülhamid dönemi sansür ile ilgili olarak Sâfî̀nin tasvir ettiği durumla karşılaştırmak için şu eserlere bakılabilir: Alpay Kabacalı, Başlangıçtan Günümüze Türkiye'de Basın Sansürü (İstanbul: Gazeteciler Cemiyeti Yayınları, 1990); Ahmet Emin Yalman, Modern Türkiye'nin Gelişme Sürecin-
} 
endişeye sevk eden sebeplerin başında da büyük ihtimalle bir gezi rehberi de olsa yazdıklarının kitap haline gelmesinde önüne çıkabilecek maniler gelmektedir. Şu cümleler, kendisinin, dostlarının ikazını haklı bulduğunu ve başına geleceğini düşündüğü sürgünden veya yazdıkları sebebiyle bedel ödemekten endişeli olduğunu gösterir: "Abdülhamid-i sânî”nin icrâ ettiği envâ'-i mezâlimden nâşi bi'z-zarure yazmak arzusundan sarf-ı nazar eyledim. Çünkü nefy olmak ve mahv edilmek var idi. Bu gibi nefy ve mahv hususları pek çok vukû bulurdu." ${ }^{18}$

Kendi ifadelerinde de anlaşıldığı üzere Ahmed Sâfî Bey'in yazmayı planladığı ve bir kısmını kaleme aldığı İstanbul Rehberi, Türkçe ve Fransızca olmak üzere iki dilli ve turistler için önemli bir ihtiyacı karşılayacak özelliktedir. İstanbul'u mahalle mahalle, semt semt inceleyen, haritalı, şehrin âhirete göçen ve yaşayan insanlarının hayat hikayelerini bir araya getiren farklı bir özelliği vardır. Ahmed Sâfî Bey, Rehnümâ kitabının aslında iki kısım olmasına karar vermiştir. Bir kısmı, şehrin inşa edilmesinden Osmanlıların fethine kadar, diğer kısmı ise fetihten, kendisinin yaşadığı zamana kadarı içine almaktadır. Kendine göre mecburi sebeplerle yaktığı bu kitabın hazırlanmasını gençlere emanet ederek, böyle bir kitap yazmalarını hem kendilerinin hem halkın istifadesi adına salık verir. ${ }^{19}$

\section{Sefînetü's-Sâfî}

Ahmed Sâfî Bey'in kaleme aldığı en dikkat çeken eser olan ve 18 cilt tutan Sefinetü's-Sâfìnin hacmi düşünüldüğünde, bu çalışmanın pek çok konuya ait başlıklara sahip olduğu görülmektedir. Müellifin son ciltte verdiği fihriste göre ciltlerdeki muhteva, kronolojik olarak yazılmamış, tematik olarak ve tasnifli ele alınmamıştır. Bu itibarla bütünlükten uzaktır. Bir konunun devamı veya başka bir açıdan ele alındığı satırlar, önceki veya sonraki ciltlerde geçebilmektedir. ${ }^{20}$

Yakın ahbaplarından Hüseyin Vassâf, Sefine'sinde, Sefinetü's-Sâfïnin 18 cildinin yazıldığını ancak peyderpey yazıldığı için devamının gelebilece-

de Basın, çev. Birgen Keşoğlu (İstanbul: Türkiye İş Bankası Kültür Yayınları, 2018).

18 Ahmed Sâfî Bey, Sefine, 18/3128.

19 Ahmed Sâfî Bey, Sefine, 18/3129. 7 Rebîülevvel 1341/28 Ekim 1922. Ahmed Sâfî Bey, Rehnümầy1 yakmak mecburiyetinde kalmaktan çok üzüntü duymuş olmalı ki Sefine'nin son cildini yazarken yine bu kitabı hatırlar: "Evrâk-1 perişanımı karıștırmakta iken bu Rehnümâ kitabının aslına âit olup devr-i Hamidî’de yaktığım evrâktan her nasılsa görülemeyip bakiye kalmıș iki aded eksik ve nâkıs varaka ele geçti. Onun üzerine bu kitap hatıra geldi, âh eyledim her ne ise fevt olan şeye teessüf beyhûdedir. Bu kitaba râci olmak üzere hatırıma gelen bazı şeyleri yazdım." der. Aynı yer.

${ }^{20}$ Müellif, eserin 18. cildinin 3350. sayfasından sonra tüm ciltlerin içindekilerini yazmak için ayrı bir sayfa numarası vermiştir. Buna göre fihrist 17 sayfa tutmaktadır. 
ğini söylemiş ${ }^{21}$, İbnü'l-Emin ise Sefine’nin 18 ciltten oluştuğunu ve "kırk anbar" gibi olduğunu, ancak basılmadığını bildirmiştir. ${ }^{22}$

İncelenen birkaç ciltten yola çıarak Ahmed Sâfî Bey’in entelektüel birikimini yazılarına yansıttığı, düşüncelerini müdafaa ettiği söylenebilir ki bu durumun tüm ciltler için geçerli olduğu düşünülebilir. Bu anlamda yazar, tasavvuf, ilm-i nücûm, edebî türler (şiir, kaside, gazel), bazı kelamî tartışmalar, ilk dönem İslam tarihi, İstanbul tarihi ve İstanbul şehir kültürüne ait kayda değer yazılar yazmıştır. Arapça ve Farsçaya vâkıf oluşu, kaside ve gazellerden anlaşılmaktadır. Bizatihi kaleme aldığı şiirlerin yanında yazdığı tahmisler de dikkati çekmektedir.

Sâfî’nin gemisi anlamına gelen Sefinetü's-Sâfînin, konu çeşitliliği açısindan Nuh'un gemisine bir gönderme yaptığı düşünülebilir. ${ }^{23}$ Yazar, "Ez'afu'l-'ibâd Ahmed Sâfî" (kulların en zayıfı) ismini kullanmış, en alta da "Câmi'u'l-hurûf" yazmıştır. Sefîne'nin 16. cildinin son sayfasına şu notu düşmüştür:

“Bu nüshadan başka Sefîne'yi yazmamak ve kalemi kırmak fikrinde idim. Ehibbâmızdan Ahmed Nazif Efendi 'îyd-i adhâ münasebetiyle fakirhânemizi teşrîf buyurmuşlardı. Sefînemiz hakkında cereyan eden sohbet neticesinde hayy esmâ-i hüsnâ-i ilâhîden olduğu ve on sekiz adedine müsâvî bulunduğu cihetle Sefîne nüshaları on sekize bâliğ olmak için iki cüzü daha yazmaklığımı tavsiye etti. Eğer ömrümüz var ise iki nüsha daha yazmaya çalışacağız." ${ }^{24}$

Ahmet Nazif Efendi'nin bu ziyareti neticesinde Ahmed Sâfî Bey, Sefine'yi 18 cilde tamamlama kararı almış ${ }^{25}$ ve "Sefine lütf-u Hakla sâhil-i selâmete erişmiştir." diyerek 5 Eylül 1340/5 Eylül 1924 Cuma günü yazmayı bitirmiş.tir. $^{26}$

Ahmed Sâfî Bey eserini yazarken bazı kitaplardan iktibaslar yapmıştır. Burada ele alınan ciltlerde İstanbul ile ilgili konular için, Naîmâ Tarihi, Hadîkatü'l-Vüzerâ, Heşt Bihişt ${ }^{27}$, Hadîkatü'l-Cevâmi', Hammer Tarihi, Mora, Istanbul ve Arnavutluk Seyahati, Hevesnâme, Lamartin'in Osmanlı Tarihi, Celâl Esad (Arseven)'in Eski İstanbul'undan istifade etmiștir. Bazı yazıların sonunda sadece eser adı verilirken bazen de metin içinde sadece eserin ismi geçmektedir. Bazı havadisleri naklederken Akşam, İkdam, Tevhid-i Efkâr

${ }^{21}$ Vassâf, Sefîne-i Evliyâa, 4/218.

22 İnal, Son Asır Türk Şairleri, 4/2036.

${ }^{23} \mathrm{~Hz}$. Nuh'un yapmış olduğu gemide hayvan ve yiyecek çeşitliliğine atıfla, Sâfî̀nin de eserini, konu çeşitliliği açısından sefine/gemi olarak isimlendirilmiş olabileceği düşünülebilir.

${ }^{24}$ Ahmed Sâfî Bey, Sefinetü's-Sâfî, 16/2774.

${ }^{25}$ Ahmed Sâfî Bey, Sefine, 16/2774.

${ }^{26}$ Ahmed Sâfî Bey, Sefine, 18/3349.

${ }^{27}$ Ahmed Sâfî Bey, Heşt Bihişt için İdrîs-i Bitlisî Tarihi ifadesini kullanmıștır. Buradan bazı şiirler iktibas etmiştir. 
gazete kupür ve nüshalarını kullanmıştır. Yazarın, el yazması veya matbu kitapları kaynak olarak kullanmasının yanında yeni dönemin haberleşme araçlarından birisi olarak gazeteyi de kullanması kitabın dikkate değer bir başka özelliğidir. Herhangi bir kitaptan faydalanmadı̆̆ı ve müktesebatına istinaden naklettiği konular için ise Câmi 'u'l-hurûf imzasını atmıştır. İstanbul tarihi ile yakından ilgili meselelerde kitap ve gazeteden başka eserine kaynaklık eden bilgiler, şahsî şahitliği ile gözlemlere, babasından ve hatırlı eş-dosttan dinledikleri ile sözlü anlatımlara dayanmaktadır.

Sefîne yazarının, satırlarında geçmişin bir muhasebesini yaptığı söylenebilir. Gerek toplumsal alanda gerekse idari meselelerde gördügü birtakım bozulmalara değinerek, eskiye dönük hayıflanmaları dikkati çekmektedir. Ancak şunu belirtmek gerekir ki Osmanlı Devleti'nde, devlet yapısının bozulmasına ilişkin değerlendirmeler Sefîne öncesinde kaleme alınan risalelerle bir külliyat oluşturmaktadır. Islahatnameler adını alan bu literatür, geleneksel devlet yapısının mevcut sıkıntılarını tespit etme ve buna yönelik çözüm önerilerini teklif eden risalelerden oluşmaktadır. Bu eserlerde öne çıkan temel mesele, askerî yapı başta olmak üzere idari ve sosyal alanlarda görülen bozuklukların "kanun-1 kadime" dönülerek düzeleceği kanaatidir. Koçi Bey, Lütfi Paşa, Selânikî Mustafa Efendi, Gelibolulu Mustafa Âlî, Kâtip Çelebi bu konuda öne çıan isimlerdir. Bu isimlerin ele aldığı konularda gerek idari gerek askerî alandaki bozulmaların başlangıç noktasının Kanuni dönemi sonrasına olduğuna dikkat çekilmektedir. Dolayısıyla düzelmenin de yine bu döneme dönülmekle olabileceğine işaret edilmektedir ki bu da iktisadî, askerî ve idarî alanlarda arayışlara yol açmıştır. ${ }^{28}$ Bu çerçevede Koçi Bey'in Sultan IV. Murad'a takdim ettiği risalede dönemin malî, siyasi, idarî bozulma ve problemlerini gözler önüne sererek bunlara dair çözüm teklifleri getirmesi ve Kanuni döneminin iyi taraflarının dikkate sunması önemlidir. ${ }^{29}$ Söz konusu islahatnamelerin üzerinden uzun bir zaman geçtikten sonra Ahmed Sâfî Bey'in geçmişe ilişkin muhasebesinde yer alan tespitler ve çözüm önerilerinin söz konusu sslahatname literatüründeki çerçeve ile paralellik teşkil ettiğini söylemek mümkündür. Bununla birlikte karamsar olduğu ve geleceğe ilişkin karamsarlığını muhafaza ettiği görülmektedir. Ona göre bir takım

${ }^{28}$ Osmanlı Devlet Düzenine Ait Metinler I Kitâb-ı Müstetâb, yay. Yaşar Yücel (Ankara: Ankara Üniversitesi Dil ve Tarih Coğrafya Fakültesi Yayınları No. 216, 1974); Osmanlı Devlet Düzenine Ait Metinler II Kitâbu Mesâlihi'l-Müslîmîn ve Menâfi'i'l-Mü'minîn, yay. Yaşar Yücel (Ankara: Ankara Üniversitesi Dil ve Tarih Coğrafya Fakültesi Yayınları-292, 1980); Kâtip Çelebi, Mîzânü’l-Hakk Fî İhtiyâri'l-Ehakk, Türkçesi. Orhan Şaik Gökyay, Süleyman Uludağ, yay. haz. Çetin Şan (İstanbul: Kabalc1 Yayınevi, 2008).

${ }^{29}$ Koçi Bey Risaleleri, haz. Seda Çakmakcıŏlu (İstanbul: Kabalcı Yayınevi, 2008), 79-86; Musa Şimşekçakan, Koçi Bey Risâlesi ve Onyedinci Yüzyıl Osmanlı Tarih Felsefesi (Marmara Üniversitesi, Sosyal Bilimler Enstitüsü, Yüksek Lisans Tezi, 1992). 
elim siyasi hadiselerin yaşanması ve geçmişten ibret alınmaması Osmanlı Devleti'nin artık ihtiyarlamış olmasına bağlı olarak, siyasetten anlayan kimsenin bulunmaması ve Kanuni'den bu yana devlete hakkı ile hizmet eden kimsenin gelmemesi sebebiyledir. Ona göre Osmanlı padişahlarının saraylarında zevk ve sefaya dalmaları, "milletin menfaat ve terakkisine" hizmet etmemeleri de bu sonuca yol açmıştır. ${ }^{30}$ Siyasi hadiseler ile ilgili değerlendirmelerine dayanarak Ahmed Sâfî Bey’in Ankara'daki Millet Meclisini ve Mustafa Kemal'i bir kurtarıcı olarak gördüğü anlaşılmaktadır. Aynı zamanda Müslümanların kardeşliğine vurgu yaparak herkesi kendine gelmeye davet etmektedir. ${ }^{31}$

\section{Sefînetï's-Sâfi'nin 16. ve 18. Ciltlerinin İstanbul Tarihi Çerçevesinde İncelenmesi}

Ahmed Sâfî Bey, 16. cildi 1 Rebîulâhir 1339/13 Aralık 1920 tarihinde Pazar günü yazmaya başlamış, 3 Eylül 1921 Cumartesi günü tamamlamıştır. Bu cilt, 2444-2774 sayfaları arasındadır. 18. cilde ise 13 Şevval 1340/10 Haziran 1922 tarihinde cumartesi günü başlanmış, cilt, 9 Ağustos 1924 tarihinde tamamlanmıştır. Ancak eserin son sayfalarında kalan boşluklara küçük bazı yazılar bu tarihten sonra da eklenmiştir. Bu itibarla yazılan son yazı 7 Haziran 1925 tarihine aittir. ${ }^{32}$ Bu cilt, arkasındaki 17 sayfa tutan fihrist haricinde, 2940 ilâ 3350 sayfaları arasındadır. Fihrist kısmı için ayrıca sayfa numarası verilmiş ve 1 rakamı ile başlanmıştır. Rika ile yazılmıştır. Kitap, sayfa usûlüne göre numaralandırılmıştır. Bazı kelimelerde ve başlıklarda kırmızı renk kullanılmıştır. Ciltlerin başında müellifin Sefine' ye başladığı ve eseri tamamladı̆̆ı zaman çekilen fotoğrafları yer almaktadir.

Ahmed Sâfî Bey'in Sefine' de şahsî şahitliklerine başvurarak yazdığı k1sımlar okunduğunda yaşadığı şehirle kurduğu organik bağ göze çarpmaktadır. Bu noktada, şehrin geçirmiş olduğu tabii afetlerin onu derinden etkilediği, yok olan tarihe olan üzüntüsünü canlı bir üslûpla dile getirdiği görülmektedir.

Ahmed Sâfî Bey'in, İstanbul'u bir bütün olarak dönem ayırt etmeden önemsediğini ve sevdiğini söylemek mümkündür. İstanbul'un Osmanlı topraklarına dahil olması ile imar alanında yaşadığı büyük dönüşüm, onun övünerek anlattı̆̆ bir büyük bir değişimdir. Bununla birlikte İstanbul'un yüzyıllar içinde geçirdiği gelişim ve imar faaliyetlerinin bazılarını tasvip etmediği, sert bir üslupla eleştirdiği görülür. Osmanlı padişahları içeri-

\footnotetext{
${ }^{30}$ Ahmed Sâfî Bey, Sefine, 16/2701-2702.

${ }^{31}$ Ahmed Sâfî Bey, Sefine, 18/3170-3172.

32 Ahmed Sâfî Bey, Sefine, 18/3349.
} 
sinde gösterişin ve Avrupaî mimarinin en fazla kendini gösterdiği dönem olan Sultan Abdülmecid dönemi başta olmak üzere Sultan Abdülaziz ve Sultan II. Abdülhamid'in saltanat yıllarını kıyasıya eleştirmektedir. Bu tenkitlerde temel dayanak noktası sarayda oturanların imar anlamında şehre verdikleri zarar ve halkın ihtiyaçlarından bîhaber olmalarıdır. Asıl tenkit ettiği ise Lale Devridir. Bununla birlikte eleştirileriyle yeni bir çözüm teklifi getirmemiştir. Bu itibarla eleştirilerinin kimi açılardan kısır kaldığg söylenebilir.

$\mathrm{Bu}$ iki ciltte İstanbul üzerine yazılanları, İstanbul ve Tabii Âfetler, İstanbul'da Ulaşım, İstanbul'un Kadim Tarihi Hazineleri, Şehrin Av Hayvanları, İstanbul ve Lale şeklinde temalara ayırmak mümkündür. Bu temalara bağlı olarak oluşturulan alt başlıklar ise bir anlamda Ahmed Sâfî Bey’in İstanbul hakkında yazdıklarının özetlenmiş halidir.

\section{1. İstanbul ve Tabii Âfetler}

3.1.1. Beyoğlu Harîk-i Kebiri (Yangını): 6 Rebîülevvel 1287 Pazar günü/ 5 Haziran 1870 İstanbul Beyoğlu'nda çıkan "harîk-i kebîr” yani büyük yangının tarif olunmaz bir dehşetle vuku bulduğunun anlatıldığ1 yazıya göre yangının şiddeti sağlam taştan inşa olunmuş kârgir binaların demirden yapılan pencere kapaklarını dahi kül etmiştir. Hasarın yaklaşık 5,5 milyon Osmanlı altını tuttuğu tahmin ve hesap edilmiştir. Ancak sadece İngiliz sigorta kumpanyası, teminatına göre 100000 Osmanlı altını tazmin etmiştir. Yangın çıktığında Sultan Abdülaziz, "Frenklerin gönlünü hoş etmek için” saraydan Beyoğlu Taksim Kışlasına gelmiştir. Yangının ardından hükümet, "harikzedelere" yani yangından zarar görenlere her gün ekmek, et, yă̆, pirinç, piyez, zeytin vermiştir. İngiliz Sarayı da yangından nasibini almıştır. Buradaki resmî evrak yanmış, İngiliz devletinin malı olan altın ve gümüş eşyalar kurtarılmıştır. Ancak sefirin ve sefaretin memurlarının kitap vb. hususi eşyaları yanmıştır. Sırp Kapı Kethüdalı̆̆ına ait bina ve Portekiz sefareti de yanmıştır. Bu yangından sonra Osmanlı topraklarında bulunan ecnebi milletlerin sefirlerinin idaresinde oluşturdukları komisyonlar tarafından herkes kendi harikzedegânına yardım parası toplayıp gerekli yerlere dağıtmıştır. Yapılan tespite göre Rum 71, Ermeni 8, Frenk Katoliği 3, Ermeni Katoliği 22 olmak üzere toplam ecnebi 104 kişi vefat etmiştir. ${ }^{33}$

Ahmed Sâfî Bey, yangın sonrasında Osmanlı topraklarının her yerinden, yangından zarar görenler için iane ${ }^{34}$ akçesinin toplandığını ve

${ }^{33}$ Ahmed Sâfî Bey, Sefine, 16/2654-2656.

34 19. yüzyılda olağanüstü durumlarda halktan toplanan mali yardımlar için kullanılır. Bk. Abdülkadir Özcan, "İane”, Türkiye Diyanet Vakfi İslâm Ansiklopedisi (İstanbul: TDV Yayınları, 1999) 
bu akçeyi verenlerin isimlerinin gazetelerde ilan edildiğini söyler. Ancak toplanan bu iane akçelerinin yangınzedelere verilmeyip Sadrazam Kapucuzade Âli Paşa'nın cebine gittiğini yazar. Bu durumu, "Harikzede Türk Müslümanları bu ianenin verilmemesinden dolayı bir daha yandı." ${ }^{35}$ cümlesiyle derin bir teessür ile ifade etmiştir. Ahmed Sâfî Bey bu felaket sonrasında yardımların yapılmadı̆̆ını iddia ederek yaşananları tenkit etmekle beraber imar düzeni ve inşaat tekniklerinin değiştirilmesine dair herhangi bir söz söylememiştir.

Gerçekten de Beyoğlu yangını, İstanbul'un 19. yüzyılda geçirdiği 200 yangın içinde dikkat çeken üç yangından birisi olarak tarihi kayıtlarda yerini almıştır. Yangının Kasım Paşa Deresi'nden Galata Sarayı'na kadar altı koldan hücum ettiği ve on üç saat sürdüğü bilinmektedir. İthal malların olduğu dükkanların, otellerin, tiyatroların ve zenginlere ait köşklerin yanması, yangının daha çok maddi açıdan büyük bir felaket olarak tanımlanmasına sebep olmuştur. Bunun yanında toplumsal açıdan da büyük bir sarsıntıya yol açmıştır. Taksim Kışlası boşaltılarak yangınzedelere ayrılmış, Talimhane bölgesine çadırlar kurulmuştur. ${ }^{36}$ Bu felaketten farklı din ve milletlerden 28689 kişi etkilenmiştir. ${ }^{37}$ Mustafa Cezar, ilk olarak bu yangında, çok sayıda felaketzedeye yardım edildiğini bildirmiştir. Bunu da Beyoğlu'nun saraylar bölgesi olmasına ve aynı zamanda okul, kışla gibi binalarla popüler bir yer haline gelmesine bağlamıştır. ${ }^{38}$

Yangın hakkında bilgi veren bazı kaynaklarda bu felaket sonrası devlet tarafından yangınzedeler için yapılan yardımlar ve günlük harcama miktarları farklılık göstermektedir. Mesela Ahmed Lütfi Efendi Tarihi'nde Ahmed Sâfî Bey'den farklı olarak yangınzedelere ceyb-i hümâyûndan (padişahın hususi bütçesinden) 10000 lira, maliye bütçesinden de 5000 lira ayrıldığı yazmaktadır. ${ }^{39}$ Harcanan günlük miktarın 150000 kuruşa ulaştığına dair bilgiler de mevcuttur. ${ }^{40}$

3.1.2. Seyelâb (Sel): 18 Zilkâde 1342/21 Haziran 1924 ve 4 Muharrem 1343/5 Ağustos 1924 tarihinde İstanbul'da çok şiddetli yağmur yağmış ve

19/228-232.

35 Ahmed Sâfî Bey, Sefine, 16/2657-2658.

${ }^{36}$ Mehmet Altun, "Beyoğlu Harîk-i Kebiri 1870 Büyük Beyoğlu Yangını", Tarih ve Toplum 39/229 (Ocak 2003), 24-35. Ayrıca bk. Son Vakanüvis Abdurrahman Şeref Efendiyle Osmanlı Tarihi Sohbetleri, haz. Mehmet Demiryürek (İstanbul: Akademik Yayınlar, 2009), 108-120.

37 Mustafa Cezar, Osmanlı Başkenti İstanbul (İstanbul: Erol Kerim Aksoy Kültür, Eğitim, Spor ve Sağlık Vakfı Yayını, 2002), 432-433.

${ }^{38}$ Mustafa Cezar, “Ondokuzuncu Yüzyılda Beyoğlu Neden ve Nasıl Gelişti”, XI. Türk Tarih Kongresi Ankara 5-9 Eylül 1990 Kongreye Sunulan Bildiriler (Ankara: Türk Tarih Kurumu Basımevi, 1994), 6/2682.

39 Ahmed Lûtfî Efendi, Vak'a-Nüvis Ahmed Lûtfî Efendi Tarihi, yay. haz. M. Münir Aktepe (Ankara: Türk Tarih Kurumu Yayınları, 1989), 95.

40 Altun, "Beyoğlu Harîk-i Kebiri 1870 Büyük Beyoğlu Yangını”, 35. 
ortaya çıkan hasar neticesinde pek çok duvarlar yıkılmış, evler çökmüştür. ${ }^{41}$ Yağmurun verdiği zararı Ahmed Sâfî Bey şu satırlarla anlatır:

"Bu şedîd yağmurdan husûle gelen seyelâb-1 azîmeden pek çok hasarât vukû bulmuştur. En çok hasar Kasımpaşa, Eyüp, Kurbağalıdere, Dolapdere, Beşiktaş, Samatya, Aksaray ve civarlarıdır. Yağmurdan akmayan ev kalmamıștır. Kasımpaşa mahallâtı arasında ahali tedarik edilen sandallara râkiben canlarını kurtarabilir. Eyüp'te ahali arabalara ve hamalların arkasına binerek ancak kurtulabilmiştir. Hükümetin ahiran icra ettiği tahkikata nazaran bu seyelâbda 400 hane bi'l-külliye münhedim ve 146 bostan mahsulâtıyla beraber kâmilen mahv ve harap oldu. Yıkılan duvarların ve ağaçların ve kısmen harap olan evlerin had ve hesabı yoktur. Makriköy ve civarında husûle gelen selden 600000 liralık hasarât vukua geldiği hükümetçe edilen tahkikattan anlaşılmıştır." ${ }^{42}$

Nuh Tufanı olarak adlandırılan bu sel felaketi hakkında dönemin gazete haberlerinde daha önceki senelerde bu aylarda böyle şiddetli bir yağışın yaşanmadığına dair yapılan haberler dikkati çekmektedir. Yağışın çokluğu dışında belediyenin tedbirsiz ve yetersizliği, alt yapının ve su yollarının yapılmamış olması mevcut yağışın bir felakete dönüşmesinin sebepleri olarak gösterilmiştir. Sel sonrası yapılan hasar tespiti çalışmalarında toplam 500000 liradan fazla bir zararın olduğu görülmüştür. Bu hususta etkili yazıların Vatan, Son Telgraf, Tanin, Cumhuriyet ve bilhassa Tevhid-i Efkâr gazetesinde yayımlandığı görülmektedir. Bu yazılarda selin büyüklüğü ve ortaya çıkan yıkımın dehşeti, İstanbul'un medeni ve modern bir belediye teşkilatına sahip olmayışı üzerinden değerlendirilerek, İstanbul'un köy hayatını sürdürdüğüne, medeni bir șehirde bu tür afetlerin yaşanmasının mümkün olmadığına işaret edilmiştir. ${ }^{43}$

\section{2. İstanbul'da Ulaşım}

3.2.1. Tramvay: Ahmed Sâfî Bey'in yazılarının satır aralarındaki özeleştiriler dikkat çekicidir. İstanbul Tramvay şirketi ile ilgili yazmış olduğu yazıda bu tür bir tenkit göze çarpar. Yazı, şirket hakkında verdiği bilgilerle başlar. İstanbul Tramvay Şirketi 8 Ağustos 1285/20 Ağustos 1869 tarihi itibariyle bir grup gayri müslim tarafindan kurulur. ${ }^{44}$ Ahmed Sâfî Bey, saydığı şirket ortaklarının içinde bir Müslüman dahi olmamasından hayıflanarak "Bu müesseselerde bir tane de Müslüman bulunsa ama bu-

${ }^{41}$ Ahmed Sâfî Bey, Sefine, 18/3346.

${ }^{42}$ Ahmed Sâfî Bey, Sefine, 18/3348-3349.

43 Önder Kocatürk, İstanbul'da Sel ve Firtına (1889-1924) (İstanbul: Boğaziçi Yayınları, 2019), 309444.

${ }^{44}$ Ahmed Sâfî Bey, Sefine, 16/2659. 
lunmaz! Biz Müslümanlar hazır yemekten başka bir şey bilmediğimizden mahvolup gidiyoruz!" değerlendirmesinde bulunur. ${ }^{45}$ Şirketleşememe, ortak iş yapamama, şahsî sermaye birikiminin olmaması ve fabrikalaşmaya yönelmemenin sebepleri devlet yapısının buna müsaade etmemesi şeklinde değerlendirilse de Ahmed Sâfî Bey bu durumu Müslümanların tembellik ve hazır yemeye mütemayil olmasına bağlar.

3.2.2. Şirket-i Hayriyye Vapuru: Boğaziçi'nde vapur işletmek üzere Şirket-i Hayriyye adıyla millî olarak tesis edilen ve bugün boğazlara vapur işleten tesisin işe başladığı tarih 1267/1850'dir. Vapuru gören bazı zengin Ermeniler "Ben de böyle vapur yaparım." diyerek Balat sahilinde bir vapur yapmışsa da makine ilmini layıkıyla bilemedikleri için vapurun makinesi 10 dakika sonra durmuş ve bu girişimci de varını yoğunu bu uğurda harcamasıyla kalmıştır. Parasızlıktan perişan olmuş, teknesini odun fiyatına satmış ve bir kilise kapısında dilencilik yapmıştır. Girişimcinin hazin sonunu anlatan Ahmed Sâfî Bey, hükümetin bu adama yard1mının olmamasını tenkit etmiştir. ${ }^{46}$

\section{3. İstanbul'un Kadim Hazineleri}

Ahmed Sâfî Bey'in yazılarında İstanbul'un tarihi hazineleri önemli yer tutmaktadır. Bu konuları kaleme alırken ilk olarak bu abidevi binaların tarihi geçmişinden bahsetmiştir. İncelenen kısımlarda İstanbul'un Bizans dönemindeki önemli eserlerine, bazı selâtin camilerine, Sünbül Sinan Tekke ve Camii'ne, Ok Meydanı'na, Sultan III. Ahmed Çeşmesi'ne yer vermiştir. Camilerin tarihi gelişimi, mimari yapısı, hatları, tabloları, kitabeleri gibi genel özellikleri, inşaat harcamaları, vakıfları, vakfiye bilgilerine dayanarak görevlileri, edebiyata konu olmaları gibi meseleler de yazılarında dikkati çekmektedir.

3.3.1. Büyük Teodosius'un Dikili Taşı: Bizans'tan günümüze kalan abidelerden çoğunun harap olduğunu söyleyen Ahmed Sâfî Bey, kalan birkaç eserden birinin Teodosius Sütunu olduğunu belirtir. Sütunun fiziki özellikleri hakkında tafsilatlı bilgi verdikten sonra üzerindeki yazılara dikkat çeker. ${ }^{47}$

3.3.2. Ayasofya Camii: Ahmed Sâfî Bey, "Ayasofya Cami-i Kebiri" başlı̆̆ında Fatih'in Ayasofya'yı vakfetmesi ve Osmanlı padişahlarının Ayasofya'ya yaptıkları ilaveler hakkında bilgi verir. Ayrıca medrese hücrelerinden ve müderrislerin vazifelerinden bahsederek “Akşemseddin'in medrese kapısı ittisalinde vaki halvethanesinin kitaphane müderrislerine

\footnotetext{
${ }^{45}$ Ahmed Sâfî Bey, Sefine, 16/2659.

${ }^{46}$ Ahmed Sâfî Bey, Sefine, 18/3050.

${ }^{47}$ Ahmed Sâfî Bey, Sefine, 16/2735-2736.
} 
verildiğini ve muîd hücresi yapıldığını" belirtir. Caminin kapıları, maksure, şamdanlar, avizeler, kandiller ve hat levhalarının menşei ve tarihi hakkında bilgiler verir. ${ }^{48}$

Ahmed Sâfî Bey, Fatih'in vakfiyesine göre Ayasofya Camii görevlilerinin toplam sayısının 86 olduğunu, Sultan I. Mahmud vakfından eklenen görevliler ile sayının 120'ye çıktığını söyler. ${ }^{49} \mathrm{Bu}$ bilgilerden sonra Ayasofya'nın fiziki ölçülerini verir. Ardından Fatih ve askerlerinin şehre girişini tasvir eder. İmparator Konstantin Dragosis'in ve onu öldüren neferin kabirlerinin Vefa'da menzilhane denilen mahalde yan yana bulunduğunu belirtir..$^{50}$

Ahmed Sâfî Bey, Bizans döneminde Ayasofya'nın inşa sürecini ayrıntılı bir şekilde aktarmışıı. İnşaat bittikten sonra yapılan törende Justinianos'un "Muazzez olsun Hüda ki böyle bir eserin inşâsına beni memur etti. Yâ Süleyman, seni geçtim!" dediğini nakleder." ${ }^{51}$ Bundan sonra Ayasofya'nın cami olduğu zamana dair bilgiler verir ve bu sırada kiliseden camiye geçişinde var olan değişiklikleri de ele alır. Ayrıca avluda yapılan değişikliklere de değinir. Ayasofya kilise iken avlunun ortasında bir havuz olduğuna işaret ederek, "O zaman kiliselere girenler evvelce yıkanmak ve temizlenmek âdet olduğundan burada ellerini, ayaklarını yıkarlardı. Hatta kilisenin derûnunda dahî böyle bir küçük tekne olup bunun üzerinde Rumca "Yalnız yüzünüzü yıkamayınız, günahlarınızı da yıkayınız." cümlesinin yazılı olduğunu nakleder. ${ }^{52}$

Ahmed Sâfî Bey Ayasofya'nın sürekli tamire ihtiyacının olmasından yakınırken bir taraftan da Rumların buradaki emellerinin devam ettiğine işaret eder. Hatta Sultanahmed Camii için ${ }^{53}$ bir zaman Ayasofya'nın devletin başına püsküllü bela olacağını anlayan Sultan Ahmed'in Ayasofya'yı yıkmak ve mahvetmek için bu camiyi inşa ettirmiş olduğunu söyler. ${ }^{54}$

3.3.3. Ka(h)riye Camii: Ahmed Sâfî Bey'in kiliseden camiye tahvil edilen Kariye Camii hakkında yazdıkları, Hadîkatü'l-Cevâmi' ve ağırlıklı olarak Eski İstanbul'dan alınmıştır. Yazısında öncelikle Kariye Camii'nin Ayasofya'dan sonra mozaikleri açısından ikici derece ehemmiyetli olduğuna dikkati çeker. Caminin Bizans dönemindeki inşasından itibaren bilgi verir ve camide yer alan mozaiklerden uzun uzun bahseder. Buranın

${ }^{48}$ Ahmed Sâfî Bey, Sefine, 16/2707-2708.

${ }^{49}$ Ahmed Sâfî Bey, Sefine, 16/2709.

${ }^{50}$ Ahmed Sâfî Bey, Sefine, 16/2711-2712.

51 Ahmed Sâfî Bey, Sefine, 16/2714.

52 Ahmed Sâfî Bey, Sefine, 16/2719.

53 Sultanahmed Camii ibadete açıldığı gün hazır bulunan ilk cemaatine öd ağacı, namazın edasindan sonra gülbenk tespih hediye edilmiştir. Ahmed Sâfî Bey, Sefine, 16/2737.

${ }^{54}$ Ahmed Sâfî Bey, Sefine, 16/2721-2722. 
camiye dönüştürülmesi hakkında verdiği bilgi yetersizdir. Cami hakkında daha fazla bilgi için müracaat eseri olarak Şarldel'in Etudes Byzanes ve Mehmed Ziya Bey'in Eski İstanbul isimli eserini tavsiye eder. ${ }^{55}$ Bu genel bilgilerin ardından Balıklı Kilisesi baş papazı ahbabının Kariye Camii hakkında mufassal Rumca bir kitap yazdığını ve bu kitabın Balıklı Kilisesi'nde bulunduğunu söyler. ${ }^{56}$

3.3.4. Süleymaniye Camii-i Şerifi: Kanuni Sultan Süleyman tarafından inşa ettirilen bu külliyeyi fizikî özellikleri ile tanıtan Ahmed Sâfî Bey, caminin haziresinde medfun bulunanları zikrettikten sonra caminin içinden ve tezyinatından, caminin mimari özelliklerinden bahseder. Ayrica camiye yapilan harcamalar hakkında bilgi verir.

3.3.5. Yeni Camii: Ahmed Sâfî Bey, yazısında cami ve sonradan ilave edilen binaların yapılışı ve harcaması hakkında bilgi verdikten sonra caminin iç mekânından bahseder ve burada detaylı bilgiler nakleder. Daha sonra caminin çevresinde olan değişiklikler hakkında bilgi verir. Deniz tarafındaki, çeşmenin bulunduğu bölümdeki ve eski postahaneye muttasıl (bitişik) haldeki kapıların kaldırıldığını söyler. Postahane karşısındaki banka şubesiyle dükkanların sonradan yapıldı̆̆ına işaret eden Ahmed Sâfî Bey, buraların kale duvarı olduğunu, bağçe kapısının Sultan Abdülaziz zamanında ortadan kaldırıldı̆̆ını söyler. Böylece caminin, çevresinde olan değişikliklerle fiziken farklılaştı̆̆ına dikkati çeker.

3.3.6. Sultan III. Ahmed Çeşmesi: Ahmed Sâfî Bey, Topkapı Sarayı'nın Bâb-1 Hümâyûn kapısı karşısında inşa edilen ve III. Ahmed Çeşmesi olarak bilinen çeşmenin mimarisine duyduğu hayranlı̆̆ı yazının başlangıcında ifade eder. Çeşmenin bir mimari harika olduğuna, "50-60 sene önce usûl-i mimariyemizin dekâik-i fenniyesine olan maharetin kemal derecede olduğuna" cümlesi ile dikkatleri çeker. Ancak bu hünere sahipken "bir zamandan beri Avrupa masnûat ve mensûcatına rağbet eylendiğini, nefis eserler vücuda getiren mimarların tamamen mahvolma derecesine geldiğini” söyler. Ahmed Sâfî Bey bu kısımda çeşmenin güzelliğine ve eşsizliğine dolaylı olarak dikkat çekmekte, henüz fizikî bir detaya girmeden bu zevk-i selimin giderek terkine olan üzüntüsünü esefle ifade eder. Ona göre bir terakkiden bahsetmek, Türklerin masnûât-1 dâhiliyyelerine rağbet ve ehl-i sınâi ve marifete hürmet eylemiş olmaları ile ancak mümkün olabilir. Bu yorumdan sonra çeşmenin inşasına dair bilgilere geçer. İnşaatta çalışanların ve göz nuru dökmüş zanaatkârların (çömlekçi, dökmeci, madenci, kalemkâr, oymacı hünerverân), kemâl-i maharet ile kabiliyetle-

55 Ahmed Sâfî Bey, Sefine, 16/2723-2729.

${ }^{56}$ Ahmed Sâfî Bey, Sefine, 16/2730. 
rini sergilemelerine dikkati çeker. Ona göre mimaride estetiği kaybetmemiz birçok Fransız mimarın Osmanlı topraklarına geldiği ve Osmanlı mimarlarının Rokokoya meylettiği döneme kadar gider. Bu tarz mimarinin yaygınlaşmasında Ermeni mimarların büyük dahli olduğuna işaret eder. Ancak aynı zamanda bu tür eserlerin halk tarafından itibar görmediğini de söyler. Yazının bundan sonraki kısmında suyun çeşmeye nasıl ulaştı̆̆ına dair tafsilatlı bilgilere yer verir. ${ }^{57}$

3.3.7. Yedikule: Ahmed Sâfî Bey'in Yedikule üzerine yazdıklarında kaynağın bulunmaması, bu bilgileri kendi bildiklerine ve şahitliklerine dayanarak yazdığını gösterir. Sözlerine, Yedikule'de Bizanslılar ve Türkler zamanında insanın tüylerini ürpertecek feci hadiselerin yaşandı̆̆ına işaret ettiği satırlarla başlar. Londra Kulesi ve Bastille Hapishanesine atıfta bulunarak Yedikule zindanlarını anlatmaya geçer: "Türkler tarafindan müteaddit defalar tamir edilmiş ve ilân-1 harp zamanlarında süferâya hapishane ittihâz olunmuştur. (Altun Kapı) denilen kapının iki tarafındaki murabba'u'ş-şekil kuleler Bizans zamanından kalmadır." Bu kapının, şehrin merasim kapısı olduğunu, imparatorların veya askerlerin harpten avdetlerinde şehre dâhil oldukları muzafferiyet kapısının defalarca tamir edildiğini söyler. Kalenin derununda bulunan mevcut kulelerden ikisi 874/1470 senesinde Sultan II. Mehmed tarafindan ilave edilmiştir. Ecnebi sefaretlerinden mahpuslar 1181/1768 senesine kadar bu kulelerin zindanlarında tutulmuştur. Bu tarihte hapse atılan Moskof elçisi Obrisko'nun hastalanması üzerine diğer elçiler padişaha ariza takdim ederek mahpusların kale dahilinde bulunan bir odada ikamet etmelerine dair izin alabilmişlerdir. İstanbul fethedildikten sonra Sultan II. Mehmed kale derununa bir cami bina ettiği gibi vakfını da Büyük Ayasofya vakfına ilhak etmiştir. Ahmed Sâfî Bey burada kulenin fiziki özellikleri hakkında bilgiler verir. Buradan "Derûn-i Kale” başlığı altında iç kalenin anlatımına geçer. Ahmed Sâfî Bey’in bildirdiğine göre kule kapısının iki tarafındaki dokuz taşa yabancı elçiler tarafından Fransızca yazılar yazılmıştır. Ahmed Sâfî Bey bu yazıların iki tanesinin kule hakkındaki yazıyı kaleme almaya başladığında mevcut olduğunu söyler. Hatta buradaki iki kıta Fransızca yazıyı Türkçeye tercüme ettirmişse de daha önce yaktığı evrakla bunlar da yanmıştır. Bu yazılardan kule derunundaki odalarda çok ise de okunmaz haldedir.

Kulenin ve mahpusların kaldıkları yerlerin tasvirlerini canlı bir şekilde veren Ahmed Sâfî Bey, bu mahalde yaşanan acı hadiselere değinir. Sultan II. Osman, Sultan II. Mehmed'in sadrazamlarından Halil ve Mahmud

\footnotetext{
${ }^{57}$ Ahmed Sâfî Bey, Sefine, 16/2761-2765.
} 
Paşalar, Girit fatihi Deli Hüseyin Paşa, Fethullah Efendi ve daha birçok meşhur isim burada vefat etmiştir.

Kulenin iç tarafinda Sultan II. Mahmud zamanına kadar elli haneli bir mahalle ve ortasında bir cami mevcuttur. 1241/1825 yilında Sultan II. Mahmud bedellerini sahiplerine vererek burayı miri araziye dahil etmiştir. Sultan II. Mahmud zamanına kadar buradaki karanlık kuleden Ramazan'da top atıldığını ve camide teravih namazı kılındığını söyler Ahmed Sâfî Bey.

Büyük kapının sağındaki kulenin adı ise Açık Kule'dir ki iç kısmında yirmi kadar hela mevcuttur. Kalenin derununda haneler yıktırilmiş ve sonra bir süre vahşi hayvanlar terbiyehanesi olarak kullanılmış, 1286/1869 senesinde Kız Sınai Mektebi yapılmış, 1296/1878'de ise kale, Maarif Nezareti'ne terk edilmiştir.

Ahmed Sâfî Bey’in yazının bir kısmını, "Kaleyi yazmaya uğraştı̆̆ım hengamda sefaret kuvvasıyla bir Moskoflu geldi ve kalenin her tarafinı gezdi." ${ }^{58}$ cümlesinden hareketle kalede yazdı̆̆ı düşünülebilir. Bu yazdıklarına ilaveten İkdam gazetesinin, André Vale'nin Nan gazetesinde Yedikule'deki yazılar üzerine yazdığı makalesinden yaptı̆̆ı alıntıya da değinir. Dahası Elçiler Kulesi adıyla bilinen kulenin kapısında mahpuslarca yazılan yazılardan da bahseder. 1263/1847 yılında İngiliz sefareti rahibi Curtis bu yazıların bir kısmını kopya etmiştir. Bu yazılardan birkaçı da 1293/1877'de Viyana'da bir mecmuada neşredilmiştir. Elçiler Kulesi'ndeki yazıların en eskisi 1101/1690'da hapsedilen ve daha sonra tahliye edilmiş olan kaptan Jule Andre Racine tarafından Latince yazılmıştır. Almanca yazıların ikisi aynı tarihte Sultan II. Mustafa'nın Macaristan seferi sırasında esir edilmiş olanlar tarafından yazılmıştır. Venedikli bir asilzade tarafından kazınmış olan Latince yazı ise Kaptan-1 derya Barbaros Hayreddin Paşa'nın Venediklilere karşı kazandığı zaferden bahsetmektedir. Buradaki en uzun yazı Venedikli diplomat Dominik Françesko'ya aittir. Bu yazılardan birisi 1215/1801 tarihinde yazılmıştır ve "Osmanlıların demirleriyle telef olan Fransızlara hatıra” sözleri, Navarin Muharebesinde esir edilen bir tabibe aittir.59

3.3.8. Ok Meydanı Dergâhı: Ahmed Sâfî Bey yazısına Ok Meydanı Mescidini anlatarak başlar. Fatih Sultan Mehmed tarafından yaptırılan mescidin, zaman içinde geçirdiği tadilatı ve camiye eklenen yapıları anlatır. Sultan III. Selim'in ve diğer okçuların kemankeş taşları olduğunu bildirir. 1233/1817 senesinde burada Sultan II. Mahmud'un kabza aldığı esnada

58 Ahmed Sâfî̀ Bey, Sefine, 18/3131-3135.

59 Ahmed Sâfî Bey, Sefine, 18/3340-3341. 
bir ziyafet tertip edildiğini ve bütün kemankeşlere mertebelerine göre padişah tarafından bohça ve atıyeler verildiğini yazar. ${ }^{60}$ Bu girișten sonra Ok Meydanı Dergâhı'na geçer. Her sene ruz-i Hızır'da açılan ve altı ay boyunca açık olan dergâhta yapılanları şöyle anlatır:

"Bu altı ay için tersaneden beheri yetmiş dirhem olmak üzere dört bin aded hâs olarak nân-1 azîz ittâ olunur. Mülûk-i sâlife-i Osmaniye vesâir ashâb-1 hayr taraflarından vakfedilmiş olan envâ'-i et'imeden mâadâ rûz-1 Hızır'da her sofra için bir aded büryan kuzu da verilir." ${ }^{1}$

Kemankeşler hakkında yazdıklarına gelince; kemankeşlerin attıkları oklarda isimlerinin yazılı olduğunu, şeyhlikte evlâdiyet olmayıp en mahir kemankeşin şeyh kabul edildiğini belirterek sözlerine başlar. Kemankeşlerin çoğu saray mensuplarından ve hadım ağalarından müteşekkildir ve Müslüman ahaliden birçok kemankeş vardır. Her hafta pazartesi ve perşembe günleri "içtima vukuunda münavebe yoluyla” kemankeşler üç s1nıfa ayrılırlar. Bir kısmı o gün ok atar, onlara o gün kemankeş denir. Bir kısmı o gün yemeğe nezaret eder ve gelen misafirleri ağırlar ki bunlara taamkeş denir. Üçüncüsü temaşaya gelen halkı kaza ve kargaşaya karşı intizamıyla muhafaza görevinde olanlardır ki bu kısma da tabankeş denir. Kemankeşler kepaze dedikleri gevşek talim yayları ile talim ederler. Bir de ok atacakları vakit kemani çektikleri zaman 'Yâ Hak' diyerek oku atarlar.

Ahmed Sâfî Bey, Sultan Abdülaziz'in arasıra dergâha geldiğini, kemankeşlere tablaya ok attırdığını, kemankeşlere 500 kuruş altın para ve bohçalar verdiğini yazar. Kemankeşlerin sinir ve zik-i sadr (nefes darlığı) illetlerinin olmadığını, ellerinin ve sair uzuvlarının titremediğini de söyler. Buna en iyi örneklerden olmak üzere Şeyhülhattatin Şeyh Hamdullah Efendi'yi verir. Şeyh Hamdullah kemankeştir ve şeyhlik unvanını hattatlıktan dolayı değil fevkalade ok attığı için almıştır.

Ahmed Sâfî Bey ok taliminin Müslümanların jimnastiği olduğunu söyler. Ardından dergâhın içindeki geziye okuyucuları da dahil eder. Ahmed Sâfî Bey’in burada esefle hayıflandığı satırlarından anlaşılır. Sultan II. Bayezid'in Okçular Başı denilen caddede okçu dükkanları olduğunu söylerken şimdi bu caddenin sadece adının kalmış olmasından derin üzüntü duyar. Bu caddede mevcut dükkanları kunduracı ve sair esnaf işgal tarafından edilmiştir. Yaşanan bu değişimden Ok Meydanı'ndaki cami ve dergâh da nasibini almış, dergahın müteferriâtı kamilen mahvolmuş ve yerleri evkaf tarafından cüzi bir akçe mukabilinde Arnavutlara ve baş-

${ }^{60}$ Ahmed Sâfî Bey, Sefine, 18/3144.

${ }^{61}$ Ahmed Sâfî Bey, Sefine, 18/3144-3145. 
kalarına kiraya verilmiştir. Bu cümlelerin ardından elimizdeki eserlere sahip çıkmayışımızı şu sitemle cümlelere döker: "(Heyhat) âsâr-ı kadime-i milliyemizi bizim için muhafaza kaydında bulunmak yoktur. Akvâm-ı sâire ise terakki ve teâliye çalışır ve âsâr-ı kadîmesini de muhafaza eder". ${ }^{62}$

3.3.9. Sünbül Sinan Tekkesi: Ahmed Sâfi Bey, bu yazıda Yenikapı Mevlevihanesi ve Sünbül Sinan Tekkesi'ndeki bazı mühim zatların vefat tarihleri ve medfun bulundukları yerler ile ilgili bilgilere yer verir. Hekimbaşı Nuh Efendi'nin evi ve medresesi buradadır. ${ }^{63}$ Bu bilgiden sonra Sünbül Efendi türbesi ve çevresine geçer. Sünbül Efendi'nin türbesi önünde bulunan ve 'Sultanlar Merkadı' olarak anılan demir parmaklıkla çevrilmiş olan yer Sultan II. Mahmud zamanında 1228/1813 senesinde yaptır1miştır. Ahmed Sâfî Bey buradaki zincirli selviden de bahseder. Bu selvi hakkında bazı yanlış inanışları tenkit eder. Bu ağacın yeşillendiği zaman İstanbul'un tekrar Rumların eline geçeceğine dair bir itikadın mevcut bulunduğuna dikkati çeker. ${ }^{64}$ Ayrıca tekkede mutad hale gelen bazı icraatlardan da bahseder. Her sene muharremin 10. günü şeyh efendinin emri ile zaviyedeki kazanlarla hazırlanan suya Sünbül Sinan'ın Sünbülüye kıraat olunmuş su ile dolu testisinden de bir miktar su ilave edilip evrâd-1 şerife okunarak gelen ahaliye bu sudan ikram edilir. ${ }^{65}$

Ahmed Sâfî Bey Sünbül Sinan türbesinde medfun olan Koca Mustafa Paşa'nın kızı Rabia Sultan'ın türbesinin hacet kapısı haline geldiğine de kısaca değinir. Halk arasında şöhret bulan hurafe ve bidatlardan yakınır.

3.3.10. Topkapı Sarayı'nda Bâbüssaâde Yakınında Üç Kürevî Levha: Ahmed Sâfî Bey, bu yazısında Topkapı Sarayının Bâbüssaâde kapısı yakınında bulunan üç levhadan bahseder. ${ }^{66}$ Osmanlı padişahlarının isimleri, cülûs tarihleri ve vefatları ile saltanat müddetlerinin yazılı olduğu bu levhaların tılsımlı olduklarını iddia eder. Hadise odur ki; Sultan II. Abdülhamid'in adı yazıldıktan sonra levhada yer kalmadığından Sultan Reşad'ın adı yazılamamış, ${ }^{67}$ bu durum padişah ve devlet erkanını devletin bekası açısından endişeye sevk etmiştir. Nihayet, padişahın yakınından birisinin "Levhalarda yer kalmaması idare-i müstebidenin hitamına işarettir. Padişahım, siz Meşrutiyet hükümdarısınız. Sizin nâm-ı hümayununuz başka bir levhaya yazılmalıdır." demesi üzerine yeni bir levha hazırlanarak muhtemel bir belanın önüne böylece geçilir. ${ }^{68}$

\footnotetext{
${ }^{62}$ Ahmed Sâfî Bey, Sefine, 18/3147-3148.

${ }^{63}$ Ahmed Sâfî Bey, Sefine, 18/3153-3155.

${ }^{64}$ Ahmed Sâfî Bey, Sefine, 18/3161-3162.

${ }^{65}$ Ahmed Sâfî Bey, Sefine, 18/3164-3165.

${ }^{66}$ Levhalar hakkında bk. Osmanlı Arşivi (BOA), Mâbeyn-İrâde [MB.̇̉], No. 160, Gömlek No. 53.

${ }^{67}$ Bk. BOA, MB.I, No. 135, Gömlek No. 39.

${ }^{68}$ Ahmed Sâfî Bey, Sefine, 18/3337.
} 


\section{4. Şehrin Av Hayvanları}

4.4.1. Kuşlar: Ahmed Sâfî Bey, İstanbul'daki av hayvanları hakkındaki yazısında bıldırcın, sülün, yelve kuşu ve keklik hakkında etraflı bilgilere yer verir. Yazdıklarından av, avcılık, av hayvanları hakkında geniş bilgiye sahip olduğu anlaşılmaktadır. Ayrıca kaybolan lezzetlere ve artık bulunmayan av hayvanlarına da değinmeden geçmez. Bu hayvanların nasıl yeneceğine dair yazdıkları, uzmanlık ölçüsünde bir damak tadına sahip olduğuna işaret eder. ${ }^{69}$

4.4.2. Balıklar: Ahmed Sâfî Bey, balıklar hakkında bazı tabirlerin ve balıkçılık ıstılahına dair kelimelerin bilinmesi gerektiğinin altını çizer. Tabirler, 1stılahlar ve balık avlamada kullanılan alet-edevatın Bizans zamanından beri kullanıldığını söyler. Karadeniz ve Marmara denizi sularında başlıca balıkların üç kısım olduğunu, bunlara yerli, geçici ve gezici balıklar ismi verildiğini bildirir. Bu balıkların başlıca av alanları dalyan ve volilerdir. Balık avının başlıcası palamut, torik, sivri ve altıparmak balıklarıdır. Ancak bunlardan başka kılıç, lüfer balıkları da tutulur. Midye, istiridye, torak gibi kabuklu hayvanların bulundukları yerler ise mutasarrıfların uhdesinde olduğundan dışarıdan kimsenin bu tarlalar dahilinde bulunması mümkün değildir. Bu açıklamalardan sonra balık çeşitlerine yine devam eder Ahmed Sâfî Bey. Uskumru, kolyoz, izmarit, kefal, kırlangıç, gelincik, kalkan, pisi, palamut, mercan, minekop, barbunya, kaya balığı (kömürcü kayası, saz kayası, hortum kayası, hurma kayası), gümüş, karagöz, hamsi, yılan balığı, mezid (tavuk balığı), levrek, mürekkep, kolyoz, lipari, terhoz, iskorbit, tarakobna, varsam, dülger balığını İstanbul'un balık çeşitleri olarak sayar. Balıklar hakkında verdiği bilgiler, balık avlama dönemleri, balık pişirme teknikleri ve daha lezzetli olan çeşidin ön plana çıkarılması şeklindedir. Hamsi balığını Lazlar, yılan balığını Almanlar severler. Büyük ve Küçük Çekmece göllerinden çıkarılan bu balığın Avrupa'ya çokça gönderildiğini yazar. Yahudiler ise yılan balığı ve hiçbir kabuklu deniz hayvanı yemezler. Kabuklu deniz hayvanları ve deniz böcekleri Hristiyanların perhiz-i kebir mevsiminde avlanarak ihraç edilir. Boğaziçi midyelerinin çoğunluğunda ise inci denilen bir ufak taşın olduğunu söyler. İçi dolu ve eti lezzetli olan midyeler Haliç dahilinde husule gelen midyelerdir. Ahmed Sâfî Bey, eskiden Müslümanların avam takımının çokluk midye yemediğini, Müslüman kadınların midyeye el bile sürmediğini anlatır. Sonraları ise midye dolması yapanlar çoğaldı̆̆ını söyler. ${ }^{70}$

Ahmed Sâfî Bey'e göre İstanbul'da Manyas ve Terkos göllerinde balıkçılık yapılmakla birlikte İstanbul'a getirilen tatlı su balıklarından sazan,

${ }^{69}$ Ahmed Sâfî Bey, Sefine, 18/3174-3175.

70 Ahmed Sâfî Bey, Sefine, 18/3179-3188. 
turna, yayın balıkları gibi başlıcalarının gıda açısından büyük önemi vardır ancak bugün Türk ahçılar içerisinde deniz mahsullerini pişiren kalmamıştır ve pişirme sanatı İslam ahçılarında maalesef gerilemiştir. ${ }^{71}$

4.5. İstanbul ve Lale: Lale için yazdıklarına Ahmed Sâfî Bey lalenin Osmanlı toprakları dışındaki şöhreti ile başlar. Sultan III. Ahmed ve Sadrazam Nevşehirli İbrahim Paşa zamanında İstanbul'un süslenmesi ve şehrin tabii güzelliği için dikilen lalelerin müsriflik olduğunu, işin tezyinden çıkıp çılgınlığa doğru gittiğini söyler. Çırağan, Said Paşa ve Neşadâbad bahçelerinde yetiştirilen lalenin hava sıcak olduğunda renkleri uçmasın diye üzerine beyaz bir örtü örtüldüğünü yine Ahmed Sâfî Bey satır aralarına yerleştirir. ${ }^{72}$ Zamanla Lale ticareti İstanbul'da cevahircilik (kuyumculuk) gibi bir sanat haline gelir. İstanbul'da 839 çeşit lale yetiştirilir Ahmed Sâfî Bey sözlerine;

"Türklerin ne kadar sefih bir kavim olduklarının anlaşılması için sefahat-i vakıayı bu münasebetle yazdım. Ey ibret nazarlı kişi malumun olsun ki Ahmed-i sâlis ve vüzerâsı bu sefahetin kurbanı oldular çünkü sefih kavim necat ve felâh bulmaz, başımıza gelen fenalıkların hepsi sefahat yüzünden gelmiştir." diyerek son verir. ${ }^{73}$

4.6. Men-i müskirat Kanunu (İçki Yasağı): Ahmed Sâfî Bey, şehir hayatına dair kanuni düzenlemelerle ilgili olarak Ankara Millet Meclisi tarafindan 14 Eylül 1920 tarihinde neşredilen ve sekiz maddeden oluşan Men-i müskirat kanununa yazısında yer verir.

Bu kanun ilk olarak Anadolu'da uygulanmış, 1923 tarihi itibariyle İstanbul'da da uygulanacağı ilan edilmiştir. Kanunun maddelerine göre memâlik-i Osmaniye'de her çeşit içki imal, idhal ve isti'mali yasaktır. Yasağa rağmen bu işleri yapanlara beher kıyye için 50 lira para cezası uygulanacak ayrıca ele geçirilen içki imha edilecektir. İçki imal edenlerin ya da gizlice içip sarhoş oldukları tespit edilenlerin hadd-i şer' ile veya 200 lira para cezası ile bu da olmazsa üç aydan bir seneye kadar hapis cezası ile cezalandırılmalarına karar verilmiştir. Bu şahısların şayet resmî görevleri var ise bu durumda memuriyetten menedilmeleri söz konusu olacaktır.

${ }^{71}$ Ahmed Sâfî Bey, Sefine, 18/3189. İstanbul'un balıkları ve balıkçılık üzerine bir çalışma için bk. Asaf Muammer, İstanbul Balık Kültürü, haz. Ruhi Güler (İstanbul: Küre Yayınları, 2015).

${ }^{72}$ Beşir Ayvazoğlu Güller Kitabı'nda şu bilgiye yer verir: "Busbecq lâleden "tulipan” diye söz ediyordu. Bazı araştırmacılar, onun gördüğ̈u lâlenin "tülbent lâlesi” adında bir Osmanlı lâlesi olduğu, dolayısıyla Avrupa dillerindeki tulip ve tulipa'nın bu "tülbent” kelimesinden geldiği görüşündedirler. Ancak Osmanlı kaynaklarında "tülbent” adında bir lâleden hiç söz edilmez." Beşir Ayvazoğlu, Güller Kitabı (İstanbul: Kapı Yayınları, 2017), 171. Burada bahsedilen tülbent lalesinin, Ahmed Sâfi Bey'in işaret ettiği lalelerin üzerine örtülen tülbentten gelmesi mümkündür.

${ }^{73}$ Ahmed Sâfî Bey, Sefine, 18/3196-3197. 
Bu husustaki hükümler itiraz ile değişikliğe uğramayacak ve temyiz edilemez şekilde düzenlenmiştir. ${ }^{74}$

Ahmed Sâfî Bey kanunun maddelerini yazdıktan sonra İstanbul'da mevcut birahane ve meyhanelerin mıntıkalarını ve sayılarını da belirtmiștir. Toplamda 2023 meyhane ve birahanenin mevcut olduğuna, meyhane sahiplerinin \%80'inin Rum olduğuna işaret etmiştir. ${ }^{75}$

\section{Sonuç}

Osmanlı son devir muharrir ve ediplerinden olan Ahmed Sâfî Bey (1851-1926) Cumhuriyet'in ilk yıllarına da şahitlik etmiş entelektüel simalardandır. Ancak kendisi günümüzde çok bilinen bir kişi olarak hafizalarda yer etmemiştir. Bunun önemli sebeplerinden birisi muhtemelen, Sefine-i Sâfî ismini verdiği 18 ciltten müteşekkil eserinin günümüz alfabesine aktarılmamış olmasıdır. Ahmed Sâfî Bey, bu çalışmasında tarihten kelama, tasavvuftan edebiyata, İstanbul tarih ve kültüründen mutfağa geniş bir alanda farklı yazılar yazmıştır. Tarih ve özellikle şehir tarihi açısından çoklu disiplinlerce çeşitli çalışmalara konu edinmeye imkân verecek özelliğe sahip, ilmî olmayan ansiklopedik bir eser olduğu söylenebilir. Bu makale, Sefine-i Sâfìnin maruf hale gelmesi, eserin 16. ve 18. ciltlerinde yer alan İstanbul özelindeki bilgileri ön plana çıkarmak maksadıyla kaleme alınmıştır. Bu iki ciltte İstanbul ile ilgili kısımlar tematik tasnif edilerek değerlendirilmiştir.

Ahmed Sâfî Bey'in, her iki ciltteki yazıları incelendiğinde yaşadı̆̆ı toplumun meselelerine bigâne kalmadığı, tecrübe ve birikimlerini sonraki kuşaklara ve bilhassa gençlere aktarmayı bir vazife şuuru ile benimsediği görülür. Onun tasavvufî ve kelamî meselelere dair yazdıkları, derin bir bilgi birikimine işaret ettiği gibi Arapça ve Farsçaya olan hakimiyeti de dikkati çeker. Edebiyata olan alakası ise eserinde Farsça ve Arapça beyit ve gazellere çokça yer vermesi ile karşımıza çıkar. Kendisinin bu iki dildeki yetkinliği, şiir gibi zor bir edebi türde yazmasından da anlaşılmaktadır. Yine eserinde zaman zaman bu iki dilden tercüme ettiği yazılara yer vermesi de tercüme edebilecek kadar bu dillere vâkıf olduğunu göstermektedir. Arapça ve Farsçadan başka Batı dillerinden Fransızcada iyi olduğu, yazmaya başlayıp sonradan siyasi endişelerle imha ettiği FransızcaOsmanlıca gezi rehberinden anlaşılmaktadır.

Sultan Abdülmecid döneminde dünyaya gelen Ahmed Sâfî Bey, son altı Osmanlı padişahının idaresini görmüş bir isimdir. Hem ülke-

${ }^{74}$ Ahmed Sâfî Bey, Sefîne, 18/3035-3036.

75 Ahmed Sâfî Bey, Sefine, 18/3037-3038. 
nin gidişatından hem de İstanbul'un ahvalinden Sultan Abdülmecid ve hususen II. Abdülhamid'i sorumlu tutmaktadır. Bir diğer ifade ile Tanzimat sonrası yaşananlar ve Meşrutiyet dönemi padişahları onun İstanbul özelinde de tenkitlerinin muhatabıdır. Hatta maddi ya da manevi herhangi bir meselede yaptığı göndermelerde ve tasvip etmediği, beceriksizlik olarak adlandırdığı bazı işlerde suçladığı isim Sultan II. Abdülhamid'dir. Aslında Osmanlı padişahlarının ve devlet ricalinin harcamalarında savurganlık, hazinenin israf edilmesi, sarayın sefahat içinde yaşaması, buna karşılık halkın başta maddi olmak üzere çeşitli sıkıntılar çekmesi hakkındaki düşünceleri Sultan III. Ahmed dönemine kadar gitmektedir. Dolayısıyla Lale devri tenkit ettiği dönemlerin başında gelir. Sultan III. Ahmed ve devlet erkanının bu sefahatin kurbanı olduklarını zira sefih olanların asla felaha ve kurtuluşa kavuşamayacaklarını ve tüm fenalıkların bu sebeple yaşandığını iddia eder. Ona göre Balkan muhacereti de yine bu beceriksizliğin ve sefahate düşkünlüğün sebebi olarak yaşanmış ve bu ağır bedel halka oradan oraya sürüklenme ile ödetilmiştir.

Ahmed Sâfî Bey Osmanlı hanedanında Kanuni sonrasını beceriksiz ve basiretsiz idareciler dönemi olarak değerlendirmektedir. Ona göre Kanuni'den sonrası için başarılı bir idareden ve idarecilerden söz etmek söz konusu olmadığı gibi Kanuni sonrası, taklidin, Batı'ya özenmenin kendini gösterdiği dönemdir. Bu itibarla Ahmed Sâfî Bey’in rahatsız olduğu Osmanlı idaresinden Cumhuriyet'e geçişte beklentilerini yüksek tuttuğu ve yeni kurulan devleti ve devletin kurucusu Mustafa Kemal'i bir kurtarıcı olarak değerlendirdiği anlaşılmaktadır. Cümlelerinde görülen Türk vurgusu, Türk gençliği hitabı, onun bir imparatorluk muharririnden çok bir Cumhuriyet dönemi muharriri olduğuna işaret etmekle beraber bir Türk milliyetçisi olduğu izlenimini de vermektedir.

Onun tenkit ettiği başka bir husus, Müslümanların içinde bulunduğu tembellik, uyuşukluk, gevşeklik ve boş vermişlik halidir. Tam da bu konuda terakki, âsar-1 kadime, kaht-1 rical, ilerlemek-geride kalmak gibi kavramlara sıklıkla değinir ve bazı karşılaştırmalar yapar. Ona göre Müslümanların bu acınası ve kopyacı hali mimariden balık pişirmeye her alanda görülmektedir. Bu onun hayıflandığı konuların başında gelmektedir. Müslümanlar her alandaki üstünlüklerini tembellikleri sebebiyle kaybetmişler, işin ilginç yanı neyi kaybettiklerinin de farkında değillerdir. Belki de bu sebepten her firsatta kaht-1 rical vurgusu yapar. Ancak bu problemlerin nasıl olacağına dair çözüm yolları teklif etmez.

Ahmed Sâfî Bey İstanbul tarihi ile yakından ilgilenmiştir. Şehri adeta bir insan gibi değerlendirerek geçmişi ve geleceği üzerine kaygılarını, 
umutlarını ve hüzünlerini aynı zamanda bilgi vererek okuyucuya aktarmıştır. İstanbul üzerine yazdıklarına bakıldığında şehrin geçirmekte olduğu mimari değişim ve dönüşümü esefle takip ettiği ve tenkitlerini ifade etmekten çekinmediği görülür. İstanbul'a karşı işlenen cürüm ve yapılan haksızlıkları aktarırken düzelmesi pek de mümkün olmayan müzmin bir hali anlatıyor gibidir. Bu açıdan sitem ve serzenişlerinin arasında kabullenilmiş çaresizliğini fazlaca hissettirir. Dolayısıyla onun İstanbul'un değişimine dair tepkileri bir kızgınlık ve küskünlük ifadesi olarak kalır.

Sefine, İstanbul'un geçirdiği değişimleri izlemeyi ve bunun takibini mümkün kılan bir şekilde rahat okunur ve anlaşılır tarzda kaleme alınmıştır. Ahmed Sâfi Bey'in kelamî ve tasavvufî konular dışında konuşur gibi yazdığı ve bu sıcak üslûbu koruduğu görülmektedir. Bu sebeple okuyucuya kimi zaman içini dökmekte, onu bu anlamda samimi bir refik gibi görmektedir. Nitekim kullandığı azizim, dostum, ey Türk gençleri gibi hitaplar bu konuşma havasını yansıtmaktadır.

Ahmed Sâfi Bey'in yaşına rağmen hafızasının berraklığı yazdıklarında görülmektedir. Özellikle İstanbul üzerine yazdıklarında dikkati çeken bu berrak hafıza, șehri ne kadar iyi tanıdığını da göstermektedir. Yazarın metin inşasında şahsî müşahedelerini de odağa aldığı dikkati çekmektedir. Tanıdıklar, eş-dost üzerinden yaptığı nakillerde bilgiyi kimden naklettiğini belirtmesi ise eser yazma kurallarına kısmen riayet çabası olarak okunabilir. Bu açıdan bakıldığında İstanbul'u gezip dolaşan ve yazan bir mahalli tarihçi olduğunu dile getirmek yanlış olmayacaktır. Ancak kimi durumlarda kendi düşüncesi diyebileceğimiz hususları herhangi bir kaynağa dayandırmadan dile getirmesi, iddia ettiği konunun şüphe ile karşılanmasına yol açabilir. İfade ettiklerini doğrulama imkânının bulunmayışı bunların birer sübjektif/yanlı yorum ve kanaat olmasının ötesine gitmeyebileceğini de akla getirmektedir. Bu sebeple metne, dönem tarihi metni muamelesi yapmak yerinde olmayacaktır. Bununla birlikte değişen İstanbul hakkında bilgi sahibi olmak ve değişimleri gözlemek, kültür tarihine, şehir kültürüne, kültür sosyolojisine dair bilgileri değerlendirmek için yazdıkları önemlidir.

Sefine-i Sâfi üzerine yapılan çalışmaların artması bilhassa İstanbul tarihi açısından bazı konuların detaylı bilinmesine katkı sağlayacak, dönem muharrirlerinin nasıl bir tahkiye oluşturduğuna dair örneklik teşkil edecek ve imparatorluktan Cumhuriyet'e geçişte yaşananları, dönemin muharrirlerinin gözünden görmeye imkân verecektir. 


\section{Kaynakça}

Ahmed Lûtfî Efendi. Vak'a-Nüvis Ahmed Lûtfî Efendi Tarihi. Yay. haz. M. Münir Aktepe. Ankara: Türk Tarih Kurumu Yayınları, 1989.

Ahmed Sâfî Bey. Sefinetü's-Sâfì. İstanbul: İstanbul Üniversitesi Tıp Fakültesi Tıp Tarihi Müzesi, 744.

Ahmed Sâfî Bey. Sefinetü’s-Sâfí. İstanbul: İstanbul Üniversitesi Tıp Fakültesi Tıp Tarihi Müzesi, 746.

Ak, Murat. "Ahmed Sâfî Bey'in Kasîde-i Hamriyye Tercümesi”. Turkish Studies, 11/17 (2016), 131-150.

Aktaş, Serap. Ahmed Sâfî Bey'in Sefinetü's-Sâfî Adlı Eserinde Bektaşîlik. İstanbul: Marmara Üniversitesi Sosyal Bilimler Enstitüsü, Yüksek Lisans Tezi, 1999.

Altun, Mehmet. “Beyoğlu Harîk-i Kebiri 1870 Büyük Beyoğlu Yangını”. Tarih ve Toplum 39/229 (Ocak 2003), 24-35.

Asaf Muammer. İstanbul Balı Kültürü. haz. Ruhi Güler. İstanbul: Küre Yayınları, 2015.

Ayvazoğlu, Beşir. Güller Kitabı. İstanbul: Kapı Yayınları, 2017.

BOA, Osmanlı Arşivi. Mâbeyn-İrâde [MB.İ], No. 160, Gömlek No. 53.

BOA, Osmanlı Arşivi. Mâbeyn-İrâde [MB.İ], No. 135, Gömlek No. 39.

Cezar, Mustafa. “Ondokuzuncu Yüzyılda Beyoğlu Neden ve Nasıl Gelişti”. XI. Türk Tarih Kongresi Ankara 5-9 Eylül 1990 Kongreye Sunulan Bildiriler. 6. Cilt. Ankara: Türk Tarih Kurumu Basımevi, 1994, 2673-2690.

Cezar, Mustafa. Osmanlı Başkenti İstanbul. İstanbul: Erol Kerim Aksoy Kültür, Eğitim, Spor ve Sağlık Vakfı Yayını, 2002.

Demirel, Fatmagül. II. Abdülhamid Döneminde Sansür. İstanbul: Bağlam Yayıncılık, 2007.

İnal, İbnü'l-Emin Mahmud Kemal. Son Asır Türk Şairleri. 4. Cilt. haz. İbrahim Baştuğ. Ankara: Atatürk Kültür Merkezi Başkanlığı Yayınları, 2002.

Kabacalı, Alpay. Başlangıçtan Günümüze Türkiye'de Basın Sansürü. İstanbul: Gazeteciler Cemiyeti Yayınları, 1990.

Karataş, Mustafa. Ahmed Sâfî Bey'in Sefinetü’s-Sâfî Adlı Eserinin VIII. Cildinin Neşri ve Ruh, Âlem-i Ervâh Açısından Değerlendirilmesi. İstanbul: Marmara Üniversitesi Sosyal Bilimler Enstitüsü, Yüksek Lisans Tezi, 1999.

Kâtip Çelebi. Mîzânü'l-Hakk Fî İhtiyâri'l-Ehakk. Türkçesi. Orhan Şaik Gökyay, Süleyman Uludağ. yay. haz. Çetin Şan. İstanbul: Kabalcı Yayınevi, 2008.

Kocatürk, Önder. İstanbul'da Sel ve Fırtına (1889-1924). İstanbul: Boğaziçi Yayınları, 2019.

Koçi Bey Risaleleri. haz. Seda Çakmakcıŏlu. İstanbul: Kabalcı Yayınevi, 2008.

Kurnaz, Cemal-Tatcı, Mustafa. “Ahmed Sâfî Bey'in Türk Dili ile İlgili Düşünceleri”. TDI. 583 (2000), 25-27.

Osmanlı Devlet Düzenine Ait Metinler I Kitâb-ı Müstetâb. yay. Yaşar Yücel. Ankara: Ankara Üniversitesi Dil ve Tarih Coğrafya Fakültesi Yayınları No. 216, 1974.

Osmanl Devlet Düzenine Ait Metinler II Kitâbu Mesâlihi'l-Müslîmîn ve Menâfi'i'l- 
Mü’minîn. yay. Yaşar Yücel. Ankara: Ankara Üniversitesi Dil ve Tarih Coğrafya Fakültesi Yayınları-292, 1980.

Osmânzâde Hüseyin Vassâf. Sefine-i Evliyâ. 4. Cilt. haz. Mehmet Akkuş-Ali Yılmaz. İstanbul: Kitabevi, 2006.

Özcan, Abdülkadir. “İane”. Türkiye Diyanet Vakfi İslâm Ansiklopedisi. 19/228-232. İstanbul: TDV Yayınları, 1999.

Son Vakanüvis Abdurrahman Şeref Efendiyle Osmanl Tarihi Sohbetleri. haz. Mehmet Demiryürek. İstanbul: Akademik Yayınlar, 2009.

Süleymaniye Kütüphanesi (SK). Süheyl Ünver Dosyası. No. 304/7, 10.

Şimşekçakan, Musa. Koçi Bey Risâlesi ve Onyedinci Yüzyıl Osmanlı Tarih Felsefesi. Marmara Üniversitesi, Sosyal Bilimler Enstitüsü, Yüksek Lisans Tezi, 1992.

Tatçı, Mustafa. “Ahmet Sâfî Bey’in Çiçekleri”. Dergâh. 187 (Eylül 2005), 19-21.

Tatçı, Mustafa-Günaydın, Yusuf T. "Ahmed Sâfî Bey'in Süleymaniye Camii Hakkındaki Düşünceleri”. Süleymaniye Ulusal Sempozyumu/Şehir ve Medeniyet. ed. Mesut Aytekin vd. 114-121. İstanbul: KOCAV, 2010.

Tıraşc1, Mehmet-Özfidan, Mustafa. “Ahmed Sâfînnin Sefînetü’s-Sâfî'sinde Mûsı1kî Bölümleri ve Ud'la İlgili Kısmın İncelenmesi”, Cumhuriyet İlahiyat Dergisi 21/2 (2017), 1249-1266.

Tosun, Necdet. “Kültür Tarihimize Işık Tutan Mühim Bir Kaynak: Sefînetü’s-Sâf̂””. ILAM Araştırma Dergisi 1/2 (Temmuz-Aralık 1996), 177-190.

Tosun, Necdet. "Ahmed Sâfî Bey", Türkiye Diyanet Vakfi İslâm Ansiklopedisi. EK-1 /50-51. İstanbul: TDV Yayınları, 2016.

Yalman, Ahmet Emin. Modern Türkiye'nin Gelişme Sürecinde Basın. çev. Birgen Keşoğlu. İstanbul: Türkiye İş Bankası Kültür Yayınları, 2018. 